\title{
Assessment of Nitrogen Leaching of Cropping Pattern by Soil Nitrogen Balance Equation (Case Study: Varamin Irrigation and Drainage Network)
}

\author{
Maryam Yousefi ${ }^{1}$, Jaber Soltani ${ }^{2}$, Ali RahimiKhob ${ }^{3}$, Mohammad Ebrahim Banihabib ${ }^{4}$ \& Elyas Soltani ${ }^{5}$ \\ ${ }^{1} \mathrm{PhD}$ student at the Dept. of Irrigation and Drainage, College of Abureyhan, University of Tehran, Iran \\ ${ }^{2}$ Assistant professor at the Dept. of Irrigation and Drainage, College of Abureyhan, University of Tehran, Iran \\ ${ }^{3}$ Professor at the Dept. of Irrigation and Drainage, College of Abureyhan, University of Tehran, Iran \\ ${ }^{4}$ Associate Professor at the Dept. of Irrigation and Drainage, College of Abureyhan, University of Tehran, Iran \\ ${ }^{5}$ Assistant professor at The Agronomy and Plant Breeding, College of Abureyhan, University of Tehran, Iran \\ Correspondence: Jaber Soltani, Assistant professor at the Dept. of Irrigation and Drainage, College of Abureyhan, \\ University of Tehran, Iran. E-mail: jsoltani@ut.ac.ir
}

Received: August 24, 2016

Accepted: December 15, 2016

Online Published: January 24, 2017

doi:10.5539/mas.v11n4p30

URL: http://dx.doi.org/10.5539/mas.v11n4p30

\begin{abstract}
Nitrogen is often one of the most important limiting factors for biomass production. Usually few soils have proper amount of nitrogen, so it is usually added by fertilizers. In cropping systems, nitrogen fertilization practices can provide a sufficient nitrogen supply for plants to achieve the potential yield. However, to ensure reaching to this potential yield, farmers often apply more nitrogen fertilizers than the required nitrogen for achieving maximum yield. Nitrogen fertilizer should be given to soil according to nitrogen content of soil, water and crop nitrogen demand during the growth periods. Especially in the lands that apply wastewater and groundwater for irrigation and irrigation sources have large quantities of nitrogen, therefore we Should reduce the amount of fertilizer used in agricultural lands, In other words for planning the plant fertilizer demand, nitrogen balance in soil should be considered. Nitrogen overuse increases the risk of nitrogen leaching to groundwater, contaminating groundwater and threatening the human health. In recent years, critical plant nitrogen concentration equation is used to determine crop nitrogen demand during the different growth stages of plants. The purpose of this study is to determine the nitrogen demand of Varamin network's cropping pattern by using the critical plant nitrogen concentration equation and comparing the result with the amount of nitrogen fertilizer commonly applied in the study area. In this study, monthly biomass production for growing period was determined based on normalized water productivity index and plant canopy development. Coefficient of critical nitrogen concentration equation for each plant was determined by previous researches. The result of this study showed that for barley, the amount of nitrogen applied in Varamin network is equal to nitrogen demand of the cropsand for wheat, maize and tomato are $25 \%, 61 \%$ and $18 \%$, respectively, higher than the amount obtained from critical plant nitrogen concentration equation.also according to the results of soil Nitrogen balance in lands covered by AU canal of Varamin network, 707 ton of nitrogen entered to soil and groundwater by leaching and we should considered appropriate solutions to reduce leaching, such as using high-yielding crops that remove a significant amount of $\mathrm{N}$ in the harvested portion, synchronizing fertilizer application with crop demand, conjunctive use of wastewater and groundwater with proper nitrogen concentration and etc.
\end{abstract}

Keywords: crop nitrogen demand, nitrogen fertilizer, cropping pattern, varamin network, Iran

\section{Introduction}

Due to the great expansion of agriculture in the arid regions and the use of nitrogen fertilizers to meet crop nutrient demand, significant amounts of this ion entered into aquifers causing serious health and environmental hazards. The amount of nitrogen fertilizer given to the land should be applied based on its soiland water availability and plant demand during the growing season.

Excessive application of nitrogen fertilizers increases nitrate leaching below the root zone. As a result, it can be harmful for human health due to contaminating the groundwater (Doltra \& Munoz 2010). 
According to statistics, the consumption of fertilizers has increased from $312 \mathrm{~kg} / \mathrm{ha}$ in $1999-2000$ to $386 \mathrm{~kg} / \mathrm{ha}$ in 2006-2007 in Iran (Sepaskhah, 2009).

Nitrate is a chemical factors that can affect the quality of drinking water andcause adverse health effects on the consumer (WHO, 2006).

Nitrogen demand of plants during the growing season is variable while most of farmers use high levels of water and nitrogen in order to ensure supplying the need of plants to water and fertilizers. Thus, nitrogen fertilizer overuse causes leaching of $\mathrm{N}$ and its transport to the groundwater aquifer (Ramos et al. 2012).

By irrigating with wastewater equivalent to 1.5 cubic meters per square meter per year, $225 \mathrm{~kg}$ of nitrogen per hectare entered to soil, that in such circumstances the use of organic and chemical nitorgen fertilizers is minimized or thoroughly eliminated (world health organization, 2006).

Assessment of Nitrogen Demand of Cropping Pattern has been studied by Critical Plant Nitrogen Concentration Index in Varamin Irrigation and Drainage Network (Yousefi, 2016).

Considerable number of studies have been carried out in order to increase the efficiency of fertilizer and water and reducing the environmental impact of agricultural activities (Plenet \& Lemaire 2000). Optimal providing of actual nitrogen needs of plants in various stages of growing based on the concept of critical nitrogen concentration is one of the possible solutions.

\section{Methods}

\subsection{Study Area}

The study area of Varamin Plain is located in the northern part of Iran and southern slopes of the Alborz Mountains, about $40 \mathrm{~km}$ south east of the Capital City, Tehran. It is located between 50o 31' to 51o 55' eastern longitude and $31 \mathrm{o}^{\prime} 9^{\prime}$ to $31 \mathrm{o} 38^{\prime}$ northern latitude. It has an area of 130000 hectare in which 50000 hectare of the plain is covered by Varamin irrigation and drainage network. Varamin network has a main canal called OABC that 9 sub-main canal branch out in O, A, B, C points. In this research, the land covered by the AU canal of Varamin network with total area of 3053 hectare, was studied. Due to water lack in the region, 2120 hectare of the total area, was under cultivation in water year 2012-2013. The Varamin irrigation network layout and location of the study area has been shownin figure 1 .

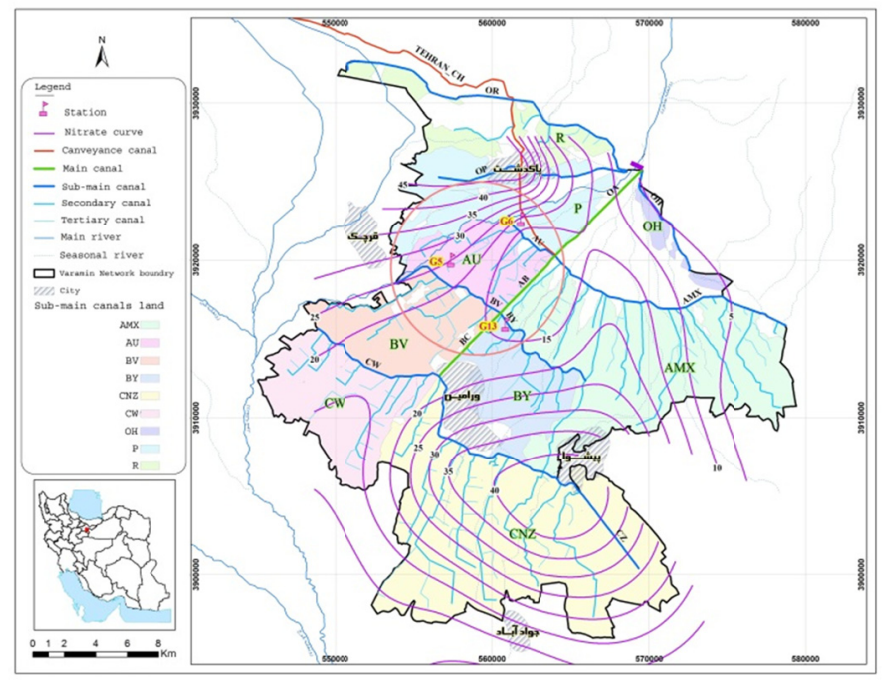

Figure 1. Varamin irrigation network layout and location of the study area

\subsection{Critical Plant Nitrogen Concentration Equation}

Plant nitrogen concentration in field crops aerial biomass can be used to defined, according to the general equation (Justes et al. 1997)

$$
\mathrm{N}_{\mathrm{ct}}=\mathrm{aDM}^{-\mathrm{b}}(1)
$$

Where DM is the amount of dry biomass accumulated in the shoots expressed in $t$ per ha and $\mathrm{N}_{\mathrm{ct}}$ is the total nitrogen concentration in shoots expressed in \% DM. Coeficient a represents plant nitrogen concentration in percent when crop mass is 1 ton per ha. Coefficient $b$ is dimensionless. Also $a$ and $b$ coefficient of equation (1) 
for each plant was determined by previous researches represented in Table 1. (Yao \& Zhao 2014). Because the value of these coefficients was not available from field studies in Iran, so we applied the average amount of a and $\mathrm{b}$ coefficient for each crop according to various studies of other countries. Note that these values are depending on physiological characteristics of plants, so they do not change much more by different climates. (Justes et al. 1994).

For computing the DM in equation 1, the AquaCrop 4 software was employed which follows the FAO bulletin No. 33. The AquaCrop is practical and useful software. Its basic concepts were developed and

also, it uses the algorithm proposed by (Raes et al. 2009). AquaCrop is the FAO crop-model to simulate yield response to water of several herbaceous crops. The model is applied for different agricultural areas throughout the world.

The average annual rainfall in the area is about $145 \mathrm{~mm}$. There is no unique pattern for the cultivation and also for the annual cultivated area. Several parameters including weather condition, cost of crop and its marketing status can affect the cultivation area and pattern. The cropping pattern of the area is presented in Table 2 . (Maharab 2013)

Table 1 . a \& b coefficient

\begin{tabular}{ccccccccc}
\hline Row & Crop & Reserches & Year & Country & $\mathrm{a}$ & $\mathrm{b}$ & Avg. a & Avg. b \\
\hline 1 & Maize & Shan-chao & 2013 & China & 2.72 & 0.27 & & \\
2 & Maize & Plenet \&Lemaire & 2000 & France & 3.4 & 0.37 & 3.16 & 0.33 \\
3 & Maize & Plenet \&Lemaire & 1999 & France & $3.38 \pm 0.091$ & $0.367 \pm 0.019$ & & \\
4 & Wheat & Yue & 2012 & China & 4.15 & 0.38 & & \\
5 & Wheat & Justes & 1994 & France & 5.35 & 0.44 & 4.64 & 0.42 \\
6 & Wheat & Yao & 2014 & China & 4.42 & 0.44 & & \\
7 & Barley & Zhao & 2014 & China & 4.73 & 0.38 & & \\
8 & Barley & Greenwood & 1990 & Scotland & 5.7 & 0.5 & 5.07 & 0.42 \\
9 & Barley & Zhao & 2014 & China & 4.8 & 0.4 & & \\
10 & Alfalfa & Lemaire & 1985 & France & $4.6-5.5$ & $-(0.29-0.36)$ & 5.05 & 0.325 \\
11 & Tomato & Justes & 1994 & France & 4.53 & 0.673 & & \\
12 & Tomato & Tei & 2002 & Italy & 4.53 & 0.327 & 4.53 & 0.5 \\
\hline
\end{tabular}

Table 2. Cropping pattern of AU canal in Varamin irrigation and drainage network

\begin{tabular}{ccc}
\hline Crop & Cultivation area(ha) & Cultivation percentage \\
\hline Wheat & 548 & 28 \\
Barley & 572 & 26 \\
Maize & 291 & 11 \\
Alfalfa & 286 & 6 \\
Tomato & 423 & 25 \\
Total & 2120 & 100 \\
\hline
\end{tabular}

\subsection{Estimation of Water Demand in Varamin Irrigation and Drainage Network}

In order to estimate the monthly water demand and planning for irrigation in Varamin irrigation and drainage network, the CROPWAT 8 software was employed. The software applies FAO Penmann-Monteith equation for computing and obtaining the potential evapotranspiration. The model uses a set of input data such as minimum and maximum daily temperature, relative humidity, wind speed and sunshine hours to estimate potential evapotranspiration. The crop evapotranspiration and irrigation planning are computed by inserting the information related to the soil and crop. Figure 2 illustrates the irrigation planning menu in the software. 


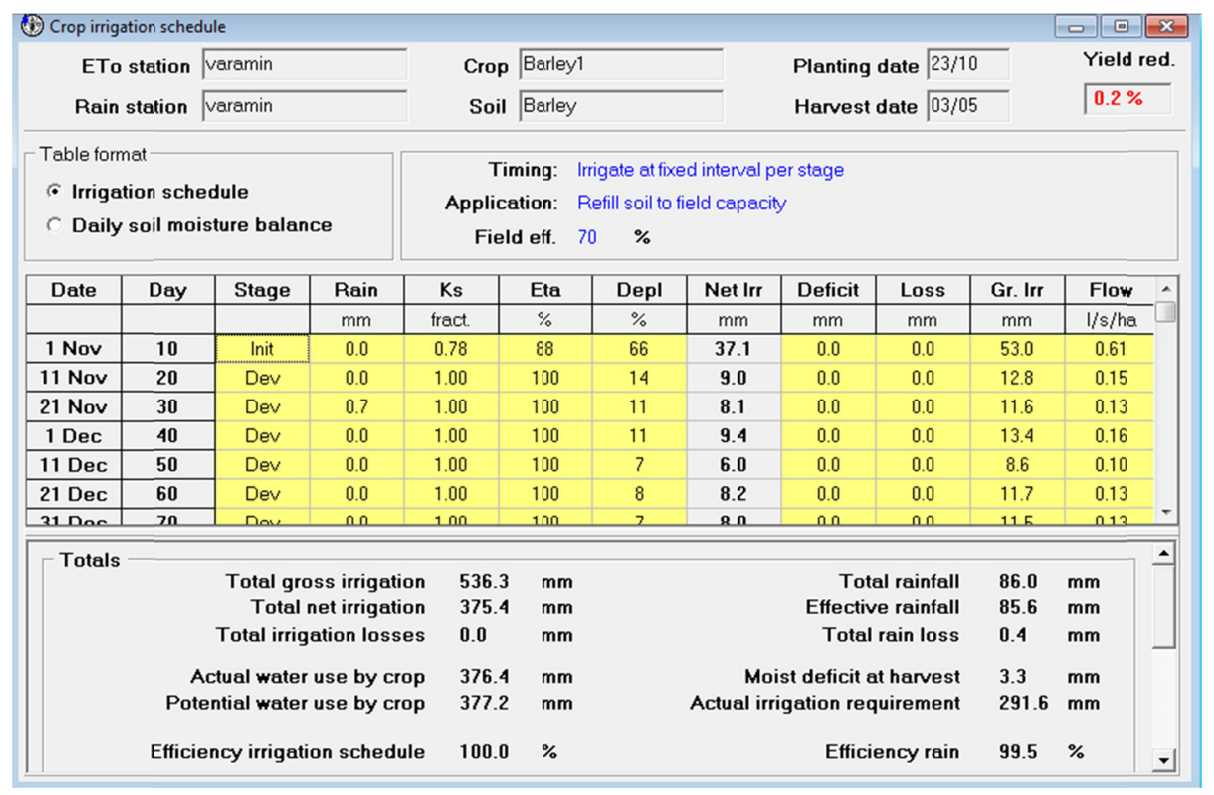

Figure 2. Crop irrigation schedule in Cropwat model

\subsection{Input Data in AquaCrop Model}

Generally, four kinds of data were applied in the model development. These data are related to weather, soil, irrigation planning and crop characteristics which are discussed in the following section.

\subsubsection{Meteorological Data}

Two kinds of meteorological data were used as input data of AquaCrop. Daily reference crop evapotranspiration computed by CropWat model and the meteorological data. Such as daily precipitation, daily minimum and maximum temperature and the pattern of $\mathrm{CO} 2$ concentration; from secondary sources.

\subsubsection{Soil Data}

The relevant soil data (Table 3) were extracted based on results of the soil test in the area.

Table 3. Soil data

\begin{tabular}{cccccc}
\hline Soil thickness & Soil texture & Saturation moisture & $\begin{array}{c}\text { Soil density } \\
\left(\mathrm{gr} / \mathrm{cm}^{3}\right)\end{array}$ & PH & EC $(\mathrm{dS} / \mathrm{m})$ \\
\hline $0-20 \mathrm{~cm}$ & Silt Loam & 44.64 & 1.37 & 7.5 & 3.55 \\
$20-40 \mathrm{~cm}$ & Sandy Loam & 43.59 & 1.24 & 7.2 & 7.75 \\
$40-60 \mathrm{~cm}$ & Sandy Loam & 40.87 & 1.32 & 7 & 4.01 \\
$60-100 \mathrm{~cm}$ & Sandy Loam & 48.58 & 1.34 & 7.6 & 1.55 \\
\hline
\end{tabular}

\subsubsection{Irrigation Requirement}

The water data required for model implementation are crop irrigation planning and water salinity. The irrigation planning is provided by the CropWat model and water salinity should be obtained through testing process. For this study, the water salinity is considered $1 \mathrm{dS} / \mathrm{m}$ according to test results.

\subsubsection{Crop Information}

Growing period of crops in AquaCrop model is divided into four stages which are initial growth, chlorophyll growth, flowering and maturity. The imported information related to the crop contains the duration of four stages of growth in day, root depth and planting distances. Rest of the crop characteristics were chosen as the model default.

\subsubsection{Results of the AquaCrop Model}

The proposed model computes the produced biomass and seed in daily, monthly and yearly time scale. The 
results are shown in Figure 3. The computational results obtained by the model were compared with the crops' yield in the area which extracted from the technical reports provided by the Ministry of Agriculture. The comparison revealed the accuracy of the model developed in this study. In this regard, more details are given in Table 4.

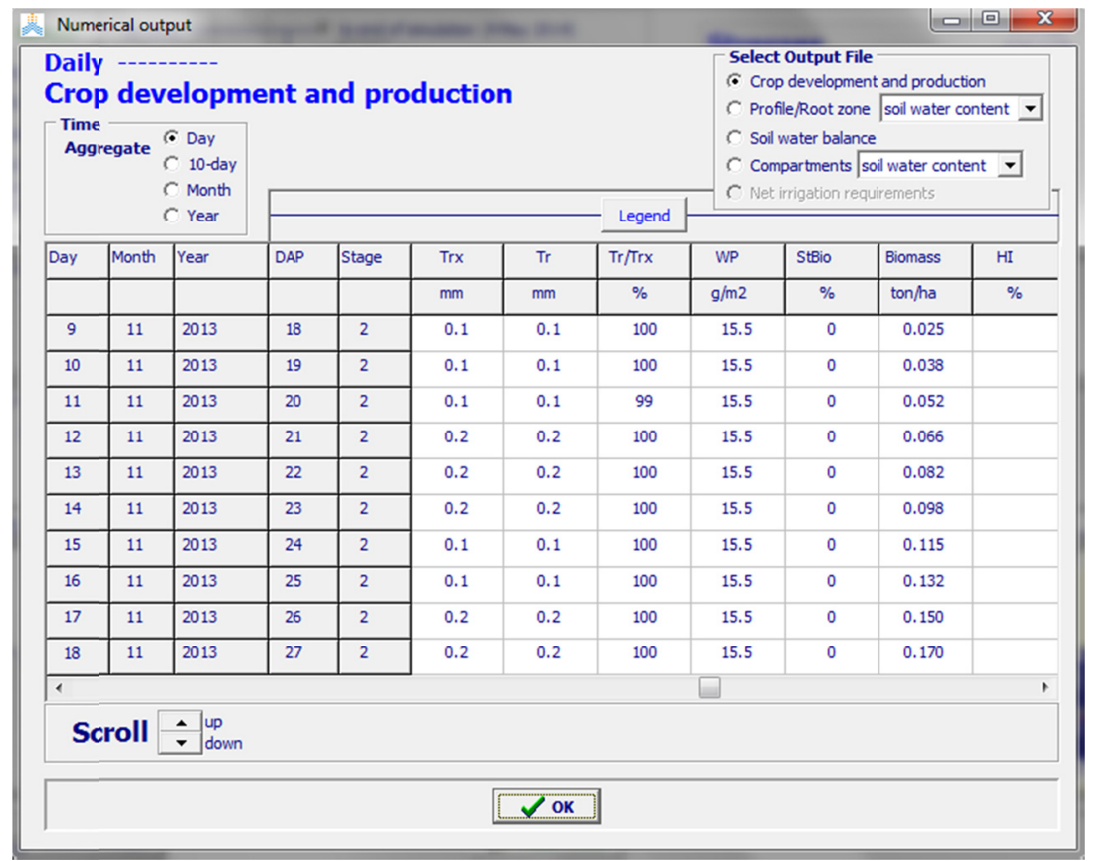

Figure 3. The results of the AquaCrop model

Table 4. Results of calculated yield by Aquacrop model in comparison of reported yield by Ministry of Agriculture

\begin{tabular}{ccc}
\hline Crop & Calculated Yield (ton/ha)- Aquacrop model & Yield (ton/ha)- reported by Ministry of Agriculture \\
\hline Wheat & 4.54 & 4.4 \\
Barley & 3.2 & 3.6 \\
Maize & 50 & 48 \\
Alfalfa & 15.47 & 14.9 \\
Tomato & 54.6 & 49.7 \\
\hline
\end{tabular}

The produced biomass and seed, critical plant nitrogen concentration, monthly nitrogen demand and the cumulative demand for cropping pattern in Varamin network were evaluated and presented in Table 5. The results are presented for example for wheat in Table 5. As shown in Table, there is an increasing trend in the nitrogen cumulative demand during growing season. It reaches to $159.3 \mathrm{~kg} / \mathrm{ha}$ in the end of the growing season while in the first month it equals to $8.4 \mathrm{~kg} / \mathrm{ha}$. The monthly nitrogen demand enhanced up to its maximum value in the flowering stage and then decreased. also Table 6 presented monthly crops' nitrogen demand of Varamin cropping pattern.

Table 5. Produced biomass and seed, critical nitrogen concentration, monthly nitrogen demand and cumulative nitrogen demand (Wheat)

\begin{tabular}{cccccccc}
\hline Growing period(month) & Nov. & Dec. & Jan. & Feb. & Mar. & Apr. & May \\
\hline Biomass(ton/ha) & 0.053 & 0.529 & 1.943 & 3.686 & 5.701 & 7.576 & 8.431 \\
Seed(ton/ha) & 0 & 0 & 0 & 0 & 0.325 & 2.42 & 4.051 \\
Critical nitrogen Concentration(gr/100gr) & 15.93 & 6.06 & 3.51 & 2.68 & 2.23 & 1.98 & 1.89 \\
Monthly nitrogen Demand(kg/ha) & 8.4 & 23.6 & 36.2 & 30.5 & 28.4 & 22.9 & 9.3 \\
Cumulative nitrogen Demand(kg/ha) & 8.4 & 32 & 68.2 & 98.7 & 127.1 & 150 & 159.3 \\
\hline
\end{tabular}


Table 6. Monthly nitrogen demand of Varamin cropping pattern $(\mathrm{kg} / \mathrm{ha})$

\begin{tabular}{cccccccccccccc}
\hline $\begin{array}{c}\text { Cropping } \\
\text { pattern }\end{array}$ & Oct. & Nov. & Dec. & Jan. & Feb. & Mar. & Apr. & May & Jun. & Jul. & Aug. & Sep. & Total \\
\hline Wheat & 8.4 & 23.6 & 36.2 & 30.5 & 28.4 & 22.9 & 9.3 & & & & & 159.3 \\
Barley & & 32.3 & 20.7 & 43.9 & 37 & 51.4 & 10.2 & & & & & 195.64 \\
Maize & & & & & & & & 10.4 & 111.6 & 64.1 & 186.1 \\
$\begin{array}{c}\text { Tomato } \\
\text { Total }\end{array}$ & & & & & & & 54.2 & 61 & 39.2 & 16.4 & 170.8 \\
\hline
\end{tabular}

Computed values attained by the equation of critical plant nitrogen concentration and they were compared with those applied fertilizer in the area (Table 7). Table 7 indicates that the amount of applied fertilizer in wheat and barley was roughly equivalent to the crop demand to nitrogen. Also, barley is a kind of gramineous crops in which it has some $\mathrm{N}$ fixing glands in its root. In this way, it supplies part of its demand to nitrogen by rhizobium bacteria on its roots. Therefore, its demand to nitrogen fertilizer decreases. The amount of fertilizer consumed for corn and tomato was about 34 and 18 per cent more than the crop demand, respectively. Therefore, the loss may transport in the form of nitrate leaching to the groundwater resources. In this regard, the consumption values of nitrogen fertilizer for these crops should be adjusted. For alfalfa, there is no need to nitrate fertilizer in real condition due to its nitrogen fixing properties. The crop provides its nitrogen demand by rhizobium bacteria on its root.

Table 7. Crop nitrogen demand in comparison of applied fertilizer in the area

\begin{tabular}{lll}
\hline Crop & Crop nitrogen demand $(\mathrm{kg} / \mathrm{ha})$ & Applied fertilizer in the area $(\mathrm{kg} / \mathrm{ha})$ \\
\hline Wheat & 159.3 & 200 \\
Barley & 195.64 & 200 \\
Maize & 186.1 & 300 \\
Tomato & 170.8 & 200 \\
\hline
\end{tabular}

\subsection{Soil Tests}

In order to determine nitrate, nitrogen and organic matter in the soil of study area, Random sampling of cropping pattern's soil in two stages in the beginning and end of the growing season was conducted, thus in area covered by AU canal, wheat, barley, maize, tomatoes and alfalfa farm, were selected and 3 soil samples were taken randomly from three points for each plant and the mentioned parameters were measured, results are presented in Table 8 and also Soil total nitrogen at the end of the cultivation season, were presented in table 9 .

Table 8. Total nitrogen, nitrate and Organic matter* of soil samples of AU canal

\begin{tabular}{|c|c|c|c|c|c|c|c|c|c|}
\hline Crop & $\begin{array}{l}\text { OM(Note } \\
2)(1) \\
(\%) \\
\end{array}$ & $\begin{array}{l}\text { OM(2) } \\
(\%)\end{array}$ & $\begin{array}{l}\text { OM(3) } \\
(\%)\end{array}$ & $\begin{array}{l}\text { Ni(Note } \\
\text { 1) (1) } \\
\text { (ppm) }\end{array}$ & $\begin{array}{l}\mathrm{Ni}(2) \\
(\mathrm{ppm})\end{array}$ & $\begin{array}{l}\mathrm{Ni}(3) \\
(\mathrm{ppm})\end{array}$ & $\begin{array}{l}\text { TN(Note 1) (1) } \\
\text { (gr N) }\end{array}$ & $\begin{array}{l}\text { TN( (2) } \\
(\text { gr N) }\end{array}$ & $\begin{array}{l}\text { TN((3) } \\
\text { (gr N) }\end{array}$ \\
\hline Wheat & 0.86 & 0.89 & 0.86 & 23.31 & 22.91 & 23.11 & 0.041 & 0.047 & 0.043 \\
\hline Barley & 1.02 & 1.09 & 1.06 & 13.8 & 13.83 & 11.74 & 0.062 & 0.065 & 0.057 \\
\hline Maize & 0.63 & 0.6 & 0.93 & 18.15 & 16.77 & 16.67 & 0.036 & 0.041 & 0.039 \\
\hline Alfalfa & 1.69 & 1.65 & 1.56 & 15.32 & 16.2 & 16.46 & 0.1 & 0.066 & 0.044 \\
\hline Tomato & 1.11 & 1.2 & 1.33 & 24.2 & 28.21 & 33.47 & 0.059 & 0.058 & 0.064 \\
\hline
\end{tabular}

*About 2 percent of soil organic matter is converted to nitrogen during the growing season (IPNI)

Table 9. Soil total nitrogen at the end of the cultivation season

\begin{tabular}{cccc}
\hline Crop & $\begin{array}{c}\text { TR(Note 3) (1) } \\
\text { (gr N) }\end{array}$ & $\begin{array}{c}\text { TR (1) } \\
\text { (gr N) }\end{array}$ & $\begin{array}{c}\text { TR (1) } \\
\text { (gr N) }\end{array}$ \\
\hline Wheat & 0.038 & 0.049 & 0.044 \\
\hline Barley & 0.052 & 0.07 & 0.062 \\
\hline Maize & 0.025 & 0.044 & 0.039 \\
\hline
\end{tabular}




\begin{tabular}{llll}
\hline Alfalfa & 0.047 & 0.081 & 0.073 \\
\hline Tomato & 0.064 & 0.063 & 0.054 \\
\hline
\end{tabular}

\subsection{Waste Water and Ground Water Tests}

To determine the amount of nitrate and total nitrogen of waste water and groundwater, Sampling waste water at the point of entry to the network (A point) and groundwater at specified wells (G5,G6,G13), in the area covered by AU canal have done monthly in water year 2012-2013. Results are shown in Table 10. For generalizing data point measurement of wells to aquifer zone, The nitrate concentration curves were drawn by the GIS software. Monitoring points and nitrate concentration curves, are shown in Figure 1.

Table 10. Amount of total nitrogen and nitrate of waste water and groundwater in monitoring points

\begin{tabular}{lcccccccccccc}
\hline Month & Oct. & Nov. & Dec. & Jan. & Feb. & Mar. & Apr. & May & Jun. & Jul. & Aug. & Sep. \\
\hline TT(Note 4)_Point A (mg/l) & 88.4 & 70 & 10 & 19 & 103.8 & 77 & 37 & 29 & 70 & 31 & 38 & 36 \\
\hline TN(Note 5)_Point A (mg/l) & 28 & 28.8 & 10.5 & 15 & 39.6 & 29.6 & 23.7 & 21 & 30 & 19.7 & 23.3 & 24.4 \\
\hline $\begin{array}{l}\text { TK(Note 6)_wells } \\
\text { (G5,G6,G13)-(mg/l) }\end{array}$ & 30 & 30 & 30 & 8.45 & 8.45 & 8.45 & 13.3 & 13.3 & 13.3 & 14.37 & 14.37 & 14.37 \\
\hline
\end{tabular}

There are different standards Such as WHO, EPA and FAO for the quality of treated wastewater for irrigating agricultural land. According to the above standards, the maximum allowable nitrate in wastewater for irrigating is as follows:

Table 11. Maximum allowable amount of nitrate in different standards

\begin{tabular}{lll}
\hline Parameter & Standard & maximum allowable amount \\
\hline \multirow{3}{*}{ NO3 } & WHO & 5 \\
\cline { 2 - 3 } & EPA & TN=30 \\
\cline { 2 - 3 } & FAO & 5 \\
\hline
\end{tabular}

As it is apparent from the table, Except in the EPA standard that maximum allowable total nitrogen is 30 in waste water, In the rest of Standards, The amount of nitrate in waste water and ground water of study area is higher than allowed amount that determined by the standard.

\subsection{Varamin Network Water Resources}

Monthly data of water resources of area covered by AU canal in year 2012-2013 is illustrated in table 12.

Table 12. Monthly data of Water Resources of AU canal in year 2012-2013 (MCM)

\begin{tabular}{cccccccccccccc}
\hline Month & Oct. & Nov. & Dec. & Jan. & Feb. & Mar. & Apr. & May & Jun. & Jul. & Aug. & Sep. & total \\
\hline VGW & 1.3 & 1.3 & 1.3 & 0.8 & 0.8 & 0.8 & 1.9 & 1.9 & 1.9 & 1.9 & 1.9 & 1.9 & 18 \\
\hline VCW & 0.45 & 0.28 & 0.53 & 0.16 & 0.46 & 0.43 & 1.14 & 1.54 & 0.54 & 0.61 & 0.48 & 0.63 & 7.3 \\
\hline Total & 1.75 & 1.58 & 1.83 & 0.96 & 1.26 & 1.23 & 3.04 & 3.44 & 2.44 & 2.51 & 2.38 & 2.53 & 25 \\
\hline
\end{tabular}

\subsection{Soil Nitrogen Balance Equation}

Soil nitrogen balance equation is presented in Eq. No. 2, this equation can be used to estimate the amount of nitrogen leaching,

$$
\begin{gathered}
\mathrm{LE}=\left[\left(\sum_{i=1}^{12} \sum_{j=1}^{5} T N_{i j}\left(V C W_{i j}\right)+\sum_{i=1}^{12} \sum_{j=1}^{5} T k_{i j}\left(V G W_{i j}\right)+\left(\sum_{i=1}^{12} \sum_{j=1}^{5} T F_{i j}\right)\left(\mathrm{A}_{\mathrm{j}}\right)+\left(\sum_{j=1}^{5} T M_{j}\right)\left(A_{j}\right)+\right.\right. \\
\left.\left(\sum_{j=1}^{5} O M_{j}\right)\left(A_{j}\right)\right]-\left[\left(\sum_{i=1}^{12} \sum_{j=1}^{5} T C_{i j}\right)\left(\mathrm{A}_{\mathrm{j}}\right)+\left(\sum_{i=1}^{12} \sum_{j=1}^{5} T D_{i j}\right)\left(\mathrm{A}_{\mathrm{j}}\right)+\left(\sum_{j=1}^{5} T R_{j}\right)\left(A_{j}\right)\right]
\end{gathered}
$$

I: month Index, $\mathrm{j}$ : crop Index, LE: Leaching $\operatorname{losses}(\mathrm{kg}), \mathrm{A}_{\mathrm{j}}$ : cultivation area(ha)(table 2$), \mathrm{TC}_{\mathrm{ij}}$ : crop nitrogen 
demand( $\mathrm{kg} / \mathrm{ha}$ ) (table 6), $\mathrm{TN}_{\mathrm{ij}}$ : total nitrogen concentration of waste water(ppm) (table 10$), \mathrm{Tk}_{\mathrm{ij}}$ : total nitrate concentration of ground water(ppm) (table 10), $\mathrm{TT}_{\mathrm{ij}}$ : waste water nitrogen concentration(ppm) (table 10), $\mathrm{TM}_{\mathrm{ij}}$ : soil total nitrogen(beginning of the cultivation season) $(\mathrm{kg} / \mathrm{ha})($ table 8$), \mathrm{OM}_{\mathrm{ij}}$ : soil organic matter(beginning of the cultivation season) $(\mathrm{kg} / \mathrm{ha}$ ) (table 8$), \mathrm{VCW}_{\mathrm{i}}$ : , $\mathrm{TR}_{\mathrm{ij}}$ : soil total nitrogen(end of the cultivation season) $(\mathrm{kg} / \mathrm{ha})$ (table 9), $\mathrm{VCW}_{\mathrm{i}}$ : volume of waste water for irrigation(MCM) (table 12), $\mathrm{VGW}_{\mathrm{i}}$ : volume of ground water for irrigation(MCM) (table 12), $\mathrm{TF}_{\mathrm{ij}}$ : fertilizer amount applied on farms $(\mathrm{kg} / \mathrm{ha}$ ) (table 7$), \mathrm{TD}_{\mathrm{ij}}$ : soil nitrogen denitrification $(\mathrm{kg} / \mathrm{ha}), \Delta \mathrm{t}: 30$ days.

Due to the small amount of ammonium in wastewater, Ammonia losses is ignored. The denitrification can be calculated by equation (3):

$$
\begin{gathered}
\left(\sum_{i=1}^{12} \sum_{j=1}^{5} T D_{i j}\right)=\left[\left(\sum_{i=1}^{12} \sum_{j=1}^{5} T T_{i j}\left(V C W_{i j}\right)+\sum_{i=1}^{12} \sum_{j=1}^{5} T k_{i j}\left(V G W_{i j}\right)+\left(\sum_{i=1}^{12} \sum_{j=1}^{5} T F_{i j}\right)\left(\mathrm{A}_{\mathrm{j}}\right)\right] *\right. \\
\left(1-\exp ^{(-0.01 \times \Delta t)}\right)
\end{gathered}
$$

By solving equation 1, the amounts of nitrogen leaching into the soil and groundwater resources annually in lands covered by the AU canal of Varamin network, was obtained 707 ton in the area that is quite an alarming amount.

\section{Conclusions}

Nitrate fertilizer consumption in farm-lands should be considered with special care and accurate planning as well. As excessive consumption of fertilizer can lead to serious environmental hazards, therefore, a good knowledge of the amount and time of Appling fertilizers, play an important role in controlling the problems and has great importance. One of the common methods is to apply critical nitrogen concentration equation in order to determine the crop nitrogen demand during the growing season. This equation determines the nitrogen demand of crop with an acceptable accuracy. The result of this study showed that for barley the amount of nitrogen applying in Varamin network is equal to nitrogen demand of the crops and for wheat, maize and tomato are $25 \%$, $61 \%$ and $18 \%$, respectively higher than the amount obtain from critical plant nitrogen concentration equation. Therefore, optimization for fertilizer consumption in these farm lands should be considered to avoid nitrogen leaching into groundwater. Also by solving the soil nitrogen balance equation, the amounts of nitrogen leaching to soil and groundwater resources Annually in lands covered by the AU canal of Varamin network, was obtained 707 ton that is a quite alarming amount. Therefore we should considered appropriate solutions to reduce leaching, such as using high-yielding crops that remove a significant amount of nitrogen in the harvested portion, synchronizing fertilizer application with crop demand, conjunctive use of wastewater and groundwater with proper nitrogen concentration and etc.

\section{References}

Doltra, J., \& Munoz, P. (2010). Simulation of nitrogen leaching from a fergated crop rotation in a Mediterranean climate using the EU-Rotate N and Hydrus-2D models. Agricultural Water Management, 97, 277-285.

International Plant Nutrition Institute (IPNI). (2011). Nitrogen in soil organic matter, how much is released in your field. Retrieved from https://ipni.net. Norcross, Georgia 30092-2844 USA

Justes, E., Jeuffroy, M. H., \& Mary, B. (1997). The nitrogen requirement for major agricultural crops: wheat, barley and durum wheat.

Justes, E., Mary, B., Meynard, J. M., Machet, J. M., \& Thelier-Huche, L. (1994). Determination of a Critical Nitrogen Dilution Curve for Wniter Wheat Crops.

Maharab Omran Gostar Consulting Engineering Company. (2013). Studies Review and Rehabilitation of Irrigation and Drainage Networks of Varamin Plain.

Plenet, D., \& Lemaire, G. (2000). Relationship between dynamics of nitrogen uptake and dry matter accumulation in maize crops. Plant Soil, 216, 65-82.

Raes, D., Studuto, P., Hsiao, Th. C., \& Fereres. E. (2009). AquaCrop - The FAO crop model to simulate yield response to water, Reference Manual January.

Ramos, T. B., Simu nek, J., Goncalves, M. C., Marns J. C., Prazeres, A., \& Pereira, L. S. (2012). Two-dimensional modeling of water and nitrogen fate from sweet srghum irrigated with fresh and blended 
saline waters. Agric. Water Manag, 111, 87-104.

Sepaskhah, A. (2009). Organic farming and water efficiency and fertilizer. Symposium of Organic Farming. Academy of Sciences, Tehran, Iran.

World Health Organization. (2006). WHO guidelines for the safe use of wastewater, excreta and greywater, Volume 2 of Wastewater use in agriculture, Geneva.

Yao, X., \& Zhao, Y. (2014). Determination of critical nitrogen dilution curve based on stem dry mater in rice. Plos one, 9(8), e104540. http://dx.doi.org/10.1371/journal.pone.0104540.

Yousefi, M., RahimiKhob, A., Soltani, J., Banihabib, M. B., \& Soltani, E. (2016). Assessment of Nitrogen Demand of Cropping Pattern by Critical Plant Nitrogen Concentration Index (Case Study: Varamin Irrigation and Drainage Network), $2^{\text {nd }}$ World. Irrigation Forum, Chiang Mai, Thailand.

\section{Notes}

Note 1. Soil total Nitrogen(beginning of the cultivation season)

Note 2. Soil nitrate

Note 3. Soil organic Matter

Note 4. Waste water nitrate

Note 5. Waste water total nitrogen

Note 6. Ground water nitrate

\section{Copyrights}

Copyright for this article is retained by the author(s), with first publication rights granted to the journal.

This is an open-access article distributed under the terms and conditions of the Creative Commons Attribution license (http://creativecommons.org/licenses/by/4.0/). 